\title{
SOCIAL RECEPTION OF NURSING IN SELECTED COUNTRIES OF THE EUROPEAN UNION
}

\author{
Zuzanna Radosz ${ }^{1 \mathrm{ABC}, \mathrm{C}, \mathrm{D}}$, Agnieszka Gniadek ${ }^{2 \mathrm{E}, \mathrm{F}}$, Halina Kulik ${ }^{3 \mathrm{E}, \mathrm{F}}$, Małgorzata Paplaczyk ${ }^{4 E}$
}

'Doctoral studies, Institute of Nursing and Midwifery, Cracow, Poland

${ }^{2}$ Faculty of Health Sciences, Institute of Nursing and Midwifery, Jagiellonian University Medical College, Cracow, Poland

${ }^{3}$ Chair and Department of Nursing Propedeutics, Faculty of Health Sciences, Medical University of Silesia in Katowice, Poland

${ }^{4}$ Department of Clinical Nursing, Institute of Nursing and Midwifery, Jagiellonian University Medical College, Cracow, Poland

Authors' contribution:

A. Study design/planning $\bullet$ B. Data collection/entry $\bullet$ C. Data analysis/statistics $\bullet D$. Data interpretation $\bullet$ E. Preparation of manuscript $\bullet$ F. Literature analysis/search $\bullet$ G. Funds collection

\author{
Address for correspondence: \\ Zuzanna Radosz \\ Institute of Nursing and Midwifery \\ 25 Kopernika St., 31-501 Cracow \\ e-mail: radosz.zuzanna@gmail.com \\ SUBMITTED: 14.08 .2021 \\ ACCEPTED: 25.08 .2021 \\ DOI: https://doi.org/10.5114/ppiel.2021.110450
}

\begin{abstract}
Aim of the study: The research aimed to identify and compare the opinions of residents of selected European countries (Poland, Portugal, France, Slovakia) on the image of a nurse.

Material and methods: The research was carried out using the diagnostic survey method by applying the survey technique. The research tool was the author's original questionnaire form. The research was conducted in 2016 in 4 European countries: Poland, Portugal, Slovakia, and France. Questionnaires were sent via the Internet. In Poland, the research was conducted in Polish, while in other countries in English. The questionnaire contained 21 questions. Results: The diversity of the nurses' social image was observed: nurses in France and Portugal enjoyed a better image than those in Poland and Slovakia. Higher scores were associated with broader knowledge about this profession and greater trust in nurses. In all the countries surveyed, the respondents pointed out that remuneration of nurses was too low. The desirable personality traits of nurses differed in all countries. In general, however, attention was paid to responsibility, attentiveness, and patience in all the countries studied.

Conclusions: There is a poorer social image among post-communist countries (Poland, Slovakia) in comparison to Western European countries (France, Portugal). In both post-communist and Western European countries, the prevailing opinion is that nursing is not a well-paid profession.
\end{abstract}

Key words: nursing, social reception, European Union.

\section{INTRODUCTION}

The social image is reflected in the media image. In turn, this is often consciously shaped in such a way as to create a public image in a given direction. With the appearance of the word image, the word stereotype has been moved slightly to the side. It can be stated that stereotypes usually concern the population and categories (e.g. stereotypes about a given nation).

In turn, prestige is a vast sphere of judgment, difficult to grasp, because you cannot see it directly. It is attributed to people for their intelligence, knowledge, appearance, position held, and successes. Therefore, it can be concluded that prestige consists of such personal qualities as reverence, respect, and dignity. Everyone has prestige, but not to the same degree. It is the other participants in social life who evaluate it. Prestige is shaped by performed roles and positions. There is an opinion that positions held increase prestige, but this does not completely determine prestige. Prestige allows you to stand out from the crowd and stop being an unnoticeable pawn [1].
Florence Nightingale was the first to draw attention to the professionalism of nursing. The realization of her idea took place through the process of shaping the nurse education model and the development of nursing as a science.

Nowadays, nursing is a recognized scientific discipline, profession, and occupation in many countries. There is also a widespread view that caring for the sick remains an art and a skill.

Despite such significant development and unquestioned social utility of nursing, there are several negative stereotypes about its contractors, which is reflected in social assessments regarding the social position and prestige of this profession.

In 1990, Briges identified 34 different stereotypes of nursing; most of them were negative. The dominance of doctors (especially men) had a strong impact on the development, image, and position of nursing. Research on the professional position of nursing shows that this profession has always been strongly subordinated to doctors. The cited studies 
also show the dissatisfaction of nurses themselves with their professional position [2, 3].

Twaddle and Hessler studied how this subordination of nursing to other occupational groups occurred. This domination began at the beginning of the $20^{\text {th }}$ century, when the strength and potential of medicine was noticed, and the position of doctors was elevated [4].

The aim of the study was to compare the image in 4 European Union countries: Poland, Slovakia, France, and Portugal.

\section{MATERIAL AND METHODS}

The study was conducted using the diagnostic survey method comprising a survey technique and proprietary survey questionnaire. The questionnaire had 21 questions. Five questions concerned sociodemographic characteristics, including the question of whether the examined person is a medical practitioner. The remaining 16 questions referred to the main topic, i.e. the social perception of the nurse. This part also included questions as to whether the respondent personally knows a nurse and would choose this profession as his/her career path.

The study was conducted in 2016 in Poland, Portugal, France, and Slovakia; 50 people were selected for the study from each country.

The respondents received a questionnaire via the Internet through a social networking site, or they were submitted directly by the first author of the paper (studies in Poland were conducted among patients hospitalized in the surgery department). The questionnaire was translated into English for respondents in France, Portugal, and Slovakia. In Poland the research was carried out in Polish. The analysis was based on a comparison of 4 groups. The analysis of research results was performed using IBM SPSS Statistics software. To this end, the following statistical tests were used:

- the $\chi^{2}$ test was used to check whether a statistically significant relationship exists between the nominal variables or between the nominal (dependent) and ordinal (independent) variables. If $p<0.05$, then the relationship was statistically significant $\left(^{*}\right)$. If $p<0.01$, then the relationship was highly statistically significant $\left(^{* *}\right)$;

- the Kruskal-Wallis test was used to check whether there was a statistically significant difference in terms of order variables between more than 2 groups. Statistically significant differences at the level of $p<0.05$ were marked with *, and statistically significant differences at the level of $p<0.01$ were marked with ${ }^{* *}$;

- Shapiro-Wilk test was used to check the normality of distributions of the analysed variables. If the $p$ value was lower than 0.01 , then the dis- tribution significantly (significantly at the level of $p<0.01)$ deviated from normal. These situations are marked with ${ }^{* *}$. If the $p$ value was lower than 0.05 , but not lower than 0.01 , then the distribution significantly (at the level of $p<0.05$ ) deviated from normal. These situations are marked with *;

- for clarity of the results described, a nurse's image index was made. It is expressed on a scale of 0-16. The higher the score, the more positive the image. Shapiro-Wilk normality distribution tests were performed in each group separately. The variable distribution of the nurse image did not differ from the normal distribution in any of the 4 compared groups. Therefore, in the further analysis, parametric variance analysis was used (ANOVA).

All people participating in the study were of legal age, and an additional criterion for conducting research in France, Portugal, and Slovakia was their knowledge of English at a level that allows them to freely complete the questionnaire.

\section{RESULTS}

The study included 200 respondents from $4 \mathrm{Eu}$ ropean countries, comprising 50 people from each of the surveyed countries: Poland, Portugal, France, and Slovakia. The medical profession was practiced by $40 \%$ of respondents from Portugal, $28 \%$ of respondents from Poland, 14\% from Slovakia, and 10\% from France. $88 \%$ of Portuguese, $74 \%$ of Poles, $74 \%$ of Slovaks, and $68 \%$ of French knew a nurse personally. Definitely more Portuguese (62\%) than French (24\%), Poles (16\%), and Slovaks (16\%) declared their readiness to choose the profession of a nurse. The result of the $\chi^{2}$ test $\left(\chi^{2}=37.169, p=0.000^{* *}\right)$ showed a high statistically significant relationship between nationality and readiness to choose the profession of a nurse. More Portuguese (62\%) and French (58\%) than Poles (32\%) and Slovaks (32\%) would recommend the profession of nurse to a member of their immediate family. The $\chi^{2}$ test $\left(\chi^{2}=16.263, p=0.012^{\star}\right)$ showed a statistically significant relationship between nationality and readiness to recommend the profession of nurse to a member of the immediate family.

Half of the Poles (50\%) believed the professional position of nurses among the medical professions is average. Every fourth (26\%) Pole believed it is low, and only $14 \%$ that it is high. In turn, $38 \%$ of Portuguese believed that this position is high or average, and $14 \%$ that it is high. The French mainly believed that the position is high or average (34\% each), and slightly less that it is low (22\%). In turn, more than half of Slovaks (55.1\%) pointed to the average position, every fourth (24.5\%) to the high position, and $14.3 \%$ to the low position. One person who did not have an opinion on this issue was excluded from the analy- 
sis. The Kruskal-Wallis test $\left(H=16.054, p=0.001^{\star *}\right)$ showed a highly statistically significant difference between the groups, where the Portuguese rated the professional position of nurses among other medical professions significantly higher than Poles (Fig. 1).

The Poles, when asked about the features of a good nurse, most often indicated responsibility $(60 \%)$, and then politeness (48\%). In turn, the Portuguese believed that a nurse should be, above all, caring (62\%) and responsible (58\%). According to the French, a good nurse is, above all, caring (50\%) and communicative (48\%), and according to the Slovaks, responsible (64\%) and then kind (44\%) - similar to the Poles' opinion (Table 1). In the case of features such as responsibility, care, communication skills, and courtesy, significant or highly statistically significant relationships with nationality were found. Responsibility was much less important for the French than for the Poles, Portuguese, and Slovaks (Table 1).

When asked about associations with the professional work of a nurse, the Poles most often pointed to low wages (62\%) and high responsibility (66\%). In turn, the Portuguese associated this work mainly with low wages (62\%) and high levels of stress (56\%). According to the French, this work primarily forced contact with human suffering (68\%), and secondly it was associated with low wages (54\%). The most common connotations of the Slovaks with the work of a nurse were high responsibility $(68 \%)$ and contact with human suffering (62\%). In the case of statements such as: high responsibility, contact with human suffering, high stress levels, and low professional prestige,

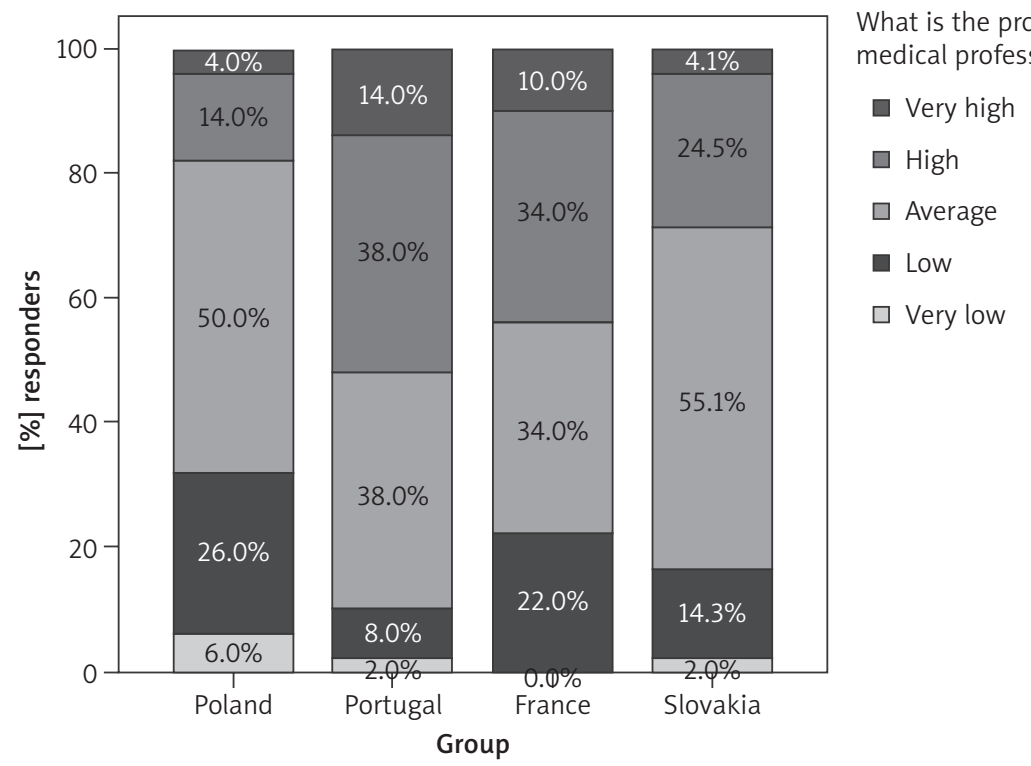

Figure 1. Characteristics of respondents including their opinions on the professional position of nursing among other medical professions

Table 1. Characteristics of respondents, taking into account their opinions on the characteristics that a good nurse should have

\begin{tabular}{|c|c|c|c|c|c|c|c|c|c|c|}
\hline \multirow[t]{3}{*}{ Features of a good nurse } & \multicolumn{8}{|c|}{ Group } & \multirow{2}{*}{\multicolumn{2}{|c|}{$\chi^{2}$ test }} \\
\hline & \multicolumn{2}{|c|}{ Poland } & \multicolumn{2}{|c|}{ Portugal } & \multicolumn{2}{|c|}{ France } & \multicolumn{2}{|c|}{ Slovakia } & & \\
\hline & $n$ & $\%$ & $n$ & $\%$ & $n$ & $\%$ & $n$ & $\%$ & $\chi^{2}$ & $p$ \\
\hline Responsible & 30 & 60.0 & 29 & 58.0 & 17 & 34.0 & 32 & 64.0 & 11.111 & $0.011^{*}$ \\
\hline Caring & 19 & 38.0 & 31 & 62.0 & 25 & 50.0 & 19 & 38.0 & 7.949 & $0.047^{\star}$ \\
\hline Patient & 17 & 34.0 & 21 & 42.0 & 19 & 38.0 & 17 & 34.0 & 0.944 & 0.815 \\
\hline Communicative & 14 & 28.0 & 21 & 42.0 & 24 & 48.0 & 11 & 22.0 & 9.582 & $0.022^{*}$ \\
\hline Attentive & 24 & 48.0 & 8 & 16.0 & 14 & 28.0 & 22 & 44.0 & 14.617 & $0.002^{* x}$ \\
\hline Careful & 14 & 28.0 & 9 & 18.0 & 20 & 40.0 & 14 & 28.0 & 5.962 & 0.113 \\
\hline Composed & 9 & 18.0 & 12 & 24.0 & 14 & 28.0 & 16 & 32.0 & 2.816 & 0.421 \\
\hline Cordial & 10 & 20.0 & 10 & 20.0 & 8 & 16.0 & 11 & 22.0 & 0.605 & 0.895 \\
\hline Honest & 6 & 12.0 & 9 & 18.0 & 3 & 6.0 & 4 & 8.0 & 4.290 & 0.232 \\
\hline Neat & 3 & 6.0 & 0 & 0.0 & 6 & 12.0 & 4 & 8.0 & 6.170 & 0.104 \\
\hline Other & 1 & 2.0 & 2 & 4.0 & 0 & 0.0 & 0 & 0.0 & 3.723 & 0.293 \\
\hline
\end{tabular}

* statistically significant relationship, * highly statistically significant relationship, $n$-total number, $\%$ - percentage of respondents 
there were statistically significant or highly significant relationships with nationality. The Poles and Slovaks more often indicated the high responsibility in the professional work of a nurse than the Portuguese and French. In turn, the contact with human suffering was more often indicated by the French and Slovaks than the Poles and Portuguese. High levels of stress were by far the most common association of the Portuguese and the rarest among the Poles. In turn, the Portuguese indicated professional prestige more often than the Poles, Slovaks, and French (Table 2).

In each of the 4 studied groups, the opinion that the nurse's salary in relations to the work performed is too low was the most common. No opinion was by far the most common answer among respondents from Slovakia. Mainly because of this, the $\chi^{2}$ test $\left(\chi^{2}=22.300, p=0.008^{\star \star}\right)$ showed a highly statistically significant correlation between nationality and the assessment of the amount of remuneration of a nurse in relation to the work they do (Fig. 2).

When asked about sources of knowledge about the profession of a nurse, the Poles most often pointed to their own experience (72\%), followed by television (52\%), private acquaintances (46\%), and information provided by friends (38\%). In turn, for the Portuguese, the most important sources of information about the profession of a nurse were as follows: own experience (60\%), television (58\%), the Internet (58\%), and infor-

Table 2. Features identified with the work of a nurse

\begin{tabular}{|c|c|c|c|c|c|c|c|c|c|c|}
\hline \multirow{3}{*}{$\begin{array}{l}\text { Features identified } \\
\text { with the work of a nurse }\end{array}$} & \multicolumn{8}{|c|}{ Group } & \multicolumn{2}{|c|}{$\chi^{2}$ test } \\
\hline & \multicolumn{2}{|c|}{ Poland } & \multicolumn{2}{|c|}{ Portugal } & \multicolumn{2}{|c|}{ France } & \multicolumn{2}{|c|}{ Slovakia } & \multirow[b]{2}{*}{$\chi^{2}$} & \multirow[b]{2}{*}{$p$} \\
\hline & $n$ & $\%$ & $n$ & $\%$ & $n$ & $\%$ & $n$ & $\%$ & & \\
\hline Low earnings & 31 & 62.0 & 31 & 62.0 & 27 & 54.0 & 24 & 48.0 & 2.828 & 0.419 \\
\hline High responsibility & 33 & 66.0 & 23 & 46.0 & 20 & 40.0 & 34 & 68.0 & 12.040 & $0.007^{\star *}$ \\
\hline Contact with human suffering & 22 & 44.0 & 21 & 42.0 & 34 & 68.0 & 31 & 62.0 & 10.145 & $0.017^{*}$ \\
\hline High level of stress & 10 & 20.0 & 28 & 56.0 & 22 & 44.0 & 19 & 38.0 & 14.123 & $0.003^{\star \star}$ \\
\hline Very high physical effort & 20 & 40.0 & 12 & 24.0 & 13 & 26.0 & 15 & 30.0 & 3.619 & 0.306 \\
\hline Low professional prestige & 9 & 18.0 & 18 & 36.0 & 8 & 16.0 & 5 & 10.0 & 11.750 & $0.008^{\star *}$ \\
\hline Dirty work & 6 & 12.0 & 6 & 12.0 & 10 & 20.0 & 7 & 14.0 & 1.734 & 0.629 \\
\hline High level of social trust & 9 & 18.0 & 4 & 8.0 & 8 & 16.0 & 4 & 8.0 & 3.794 & 0.285 \\
\hline Exposure to harmful agents & 7 & 14.0 & 6 & 12.0 & 5 & 10.0 & 6 & 12.0 & 0.379 & 0.945 \\
\hline Clean work & 1 & 2.0 & 0 & 0.0 & 2 & 4.0 & 1 & 2.0 & 2.041 & 0.564 \\
\hline High earnings & 0 & 0.0 & 1 & 2.0 & 0 & 0.0 & 3 & 6.0 & 6.122 & 0.106 \\
\hline High professional prestige & 2 & 4.0 & 0 & 0.0 & 0 & 0.0 & 1 & 2.0 & 3.723 & 0.293 \\
\hline
\end{tabular}

* statistically significant relationship, ${ }^{* *}$ highly statistically significant relationship, $n$-total number, \% - percentage of respondents

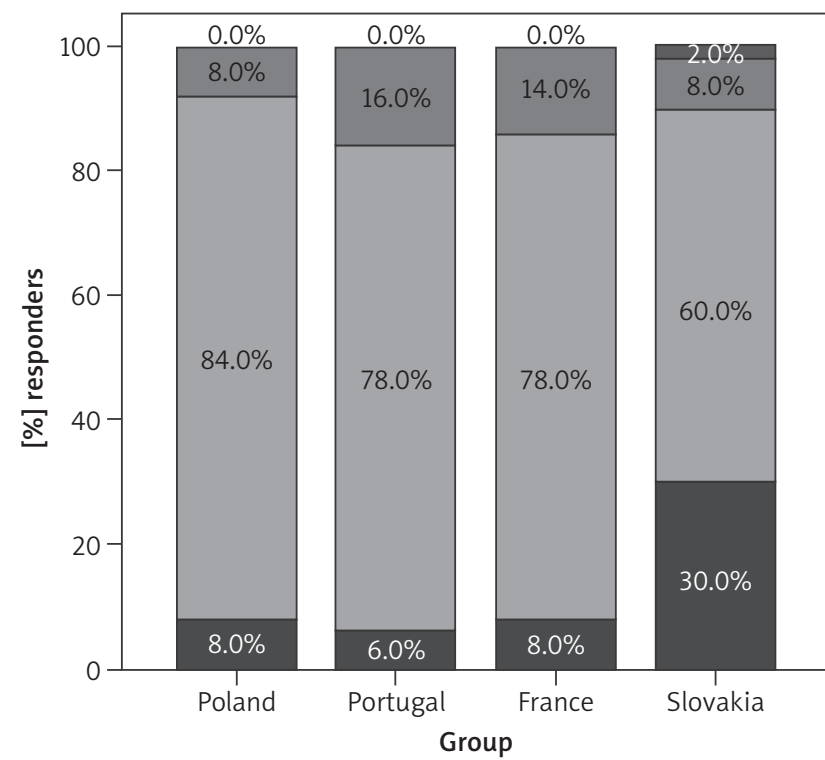

What is the average remuneration for nurses compared to the work they perform?
- Too high
$\square$ Suitable
$\square$ Too low
- I don't know

Figure 2. Characteristics of respondents, including their opinions on the amount of remuneration for a nurse 
mation received from friends (40\%). The French most often pointed to the Internet (60\%), and then to their own experience (46\%), television (46\%), information provided by friends (38\%), and private acquaintances (36\%). For Slovaks, the main sources of information were their own experience (60\%) and television (58\%), followed by information from friends (40\%), the Internet (36\%), and private acquaintances (36\%). In the case of the Internet and other sources, a highly significant and significant relationship with nationality was found. In the case of the participants' own experience and private acquaintances, the relationships were close to statistical significance. The Poles most often pointed to their own experience, and the French the least frequently. The Portuguese and French more often pointed to the Internet than did the Poles and Slovaks.

According to the Poles, the professional group of nurses in the media is mainly depicted during strikes (88\%) and in feature programs and TV series (88\%), and slightly less often in documentaries and reportages (52\%). In turn, the Portuguese most often pointed to strikes (78\%), followed by feature programs and TV series (66\%) and documentary programs and reportages (66\%). According to the French, nurses are shown in the media because of strikes $(78 \%)$ in feature programs and series (72\%) and in documentary programs and reportages (72\%). In turn, the Slovaks most often pointed to strikes (82\%) and feature programs and TV series (74\%), followed by the professional successes of medical teams (46\%) and documentaries and reportages (40\%). Far more Portuguese and French than Poles and, above all, Slovaks pointed to documentary programs and reportages. In turn, advertising campaigns were indicated by more Portuguese and Slovaks than by Poles and French (Table 3 ).

More Poles (22\%) and Slovaks (26\%) than Portuguese (12\%) and French (12\%) were of the opinion that the image of nurses created in the media strengthens the professional position of this group. In each of the

Table 3. Characteristics of respondents, taking into account their opinions on the circumstances in which the professional group of nurses is most often presented in the media

\begin{tabular}{|c|c|c|c|c|c|c|c|c|c|c|}
\hline \multirow{3}{*}{$\begin{array}{l}\text { Circumstances in which the professional } \\
\text { group of nurses is most often presented } \\
\text { in the media }\end{array}$} & \multicolumn{8}{|c|}{ Group } & \multirow{2}{*}{\multicolumn{2}{|c|}{$\chi^{2}$ test }} \\
\hline & \multicolumn{2}{|c|}{ Poland } & \multicolumn{2}{|c|}{ Portugal } & \multicolumn{2}{|c|}{ France } & \multicolumn{2}{|c|}{ Slovakia } & & \\
\hline & $n$ & $\%$ & $n$ & $\%$ & $n$ & $\%$ & $n$ & $\%$ & $\chi^{2}$ & $p$ \\
\hline Strikes & 44 & 88.0 & 39 & 78.0 & 39 & 78.0 & 41 & 82.0 & 2.222 & 0.528 \\
\hline Feature programs. TV series & 44 & 88.0 & 33 & 66.0 & 36 & 72.0 & 37 & 74.0 & 6.933 & 0.074 \\
\hline Advertising campaigns & 8 & 16.0 & 19 & 38.0 & 9 & 18.0 & 15 & 30.0 & 8.501 & $0.037^{*}$ \\
\hline Celebration of World Nurse Day (May 12) & 12 & 24.0 & 13 & 26.0 & 11 & 22.0 & 13 & 26.0 & 0.297 & 0.961 \\
\hline
\end{tabular}

* statistically significant relationship, ${ }^{* *}$ highly statistically significant relationship, $n$-total number, $\%$ - percentage of respondents

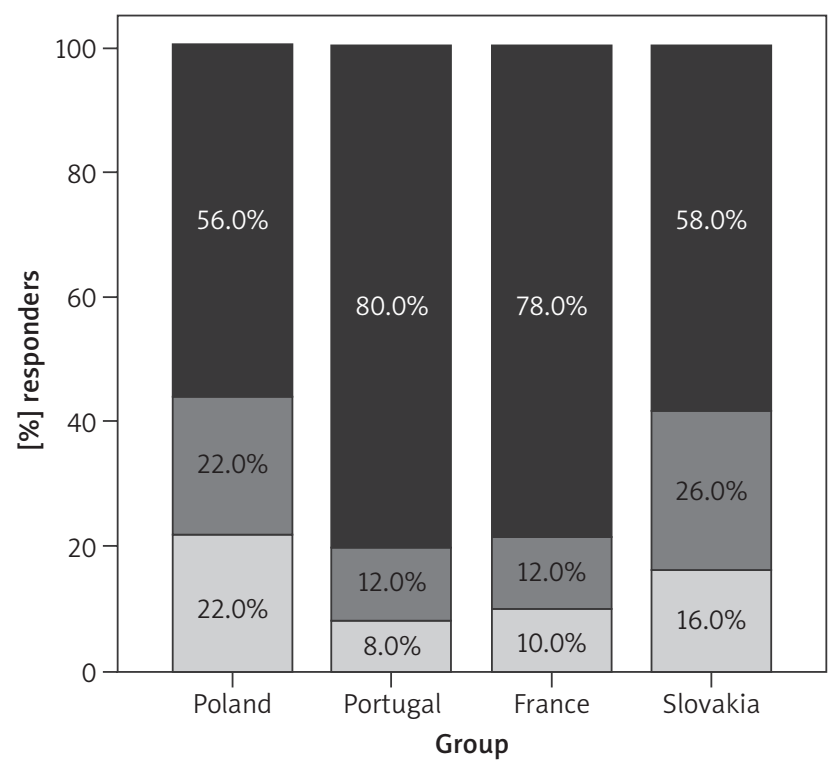

Does the image of nurses created in the media strengthens the professional position of this group?
no
$\square$ Yes
$\square$ I don't know

Figure 3. Characteristics of respondents, including their opinions on the media image of nurses 
groups, however, the opposite view prevailed. The $\chi^{2}$ test $\left(\chi^{2}=12.096, p=0.060\right)$ showed a close relationship between nationality and opinion about whether the image of nurses created in the media strengthens the professional position of this group (Fig. 3).

The average assessment of the image of a nurse in Portugal $(M=9.86)$ and France $(M=9.16)$ was much higher than in Poland $(M=7.48)$ and Slovakia $(M=7.76)$. The analysis of variance $(F=9.577$, $\left.p=0.000^{* *}\right)$ showed highly statistically significant differences between the groups. Tukey's multiple comparison test showed, however, that the image of nurses in Portugal and France was significantly more positive than in Poland and Slovakia. The graphical distribution of data is presented in Figure 4.

\section{DISCUSSION}

Determining the social status of nursing, due to the complexity of this issue, is difficult to interpret. On the one hand, factors such as higher education, work complexity, responsibility, and social significance of work performed are considered. However, there is still a conviction in society that a nurse is a doctor's assistant, not a partner in action. It is also worth emphasizing that despite the low attractiveness of this profession, nursing occupies a high place in the ranking of satisfaction with the profession. In the 2011 ranking conducted by Kołodziej, as many as $81 \%$ of surgical nurses found their work satisfactory. Awareness of the high social usefulness of a nurse's work related to saving health and human life is undoubtedly a factor determining the sense of meaning of the work [5].

In the era of professional and social changes, the importance of social image increases. Poland's accession to the European Union initiated several profound changes in this profession. These changes concerned both the organization of nurses' education and their competences. Currently, to become a nurse, you must graduate with a bachelor's degree - it is a prerequisite for obtain the right to practice. It is also possible to continue studies as part of the master's studies and at the next level of qualifications (medical school). The competences of nurses have also expanded. They have greater independence in undertaking and implementing tasks in the area of health promotion and health education. However, there is no doubt that in Poland the conviction that the nurse is subordinated to the doctor in all her or his decisions still dominates [6]. The research conducted herein shows that only $58 \%$ of the Poles thought that nursing was an independent profession. This is the smallest number of indications among the surveyed nationalities. A slightly higher percentage (62\%) of the Slovak population expressed a similar opinion. This data can be referred to the 2011 study on the image of nurses among doctors

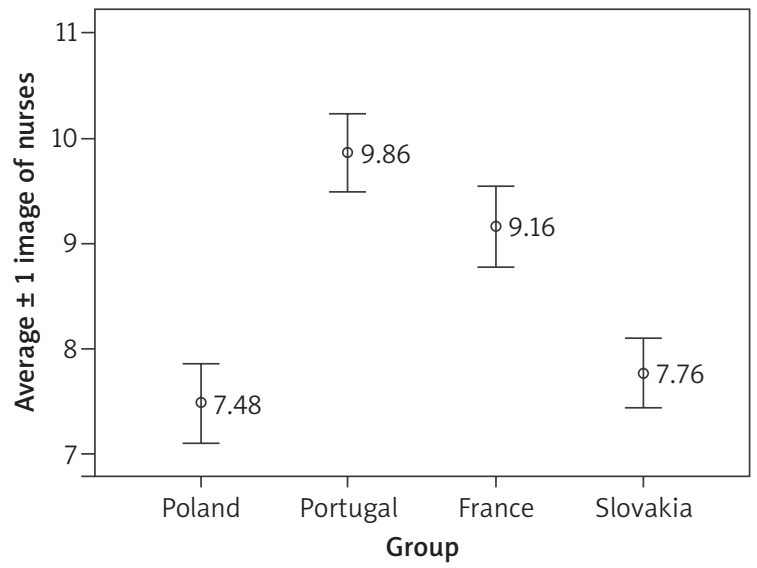

Figure 4. Comparison of the image of nurses in Poland, France, Portugal, and Slovakia

and patients. Interestingly, patients are more often considered by nurses to be independent and disciplined than doctors [6].

Respectively, $14 \%$ and $24.5 \%$ of Poles and Slovaks believed that the professional position of nursing is low among other medical professions. The same position is indicated by $8 \%$ of the Portuguese and $22 \%$ of the French, which indicates a lower image index among the surveyed post-communist countries (Poland, Slovakia) compared to countries from Western Europe (France, Portugal). Further examples confirm this thesis. In Poland and Slovakia, the respondents indicated the therapeutic function of a nurse (carrying out the doctor's orders) much more often than in France and Portugal. All study groups agreed on in one area: earnings. Both post-communist countries and Western European countries mostly believed that nursing is not a well-paid profession. Despite this, as many as $62 \%$ of Portuguese would be willing to choose the profession of nurse as their career path.

Poles, compared to the Portuguese, did not know that a nurse can undertake a medical specialisation. Perhaps this was because the Polish identifiers rarely use phrases such as "a nurse, a specialist in nursing". It is also worrying that fewer and fewer people decide to study nursing. In 2014, 25,539 people became nursing graduates in France. In Portugal, 2674 people, 2868 in Slovakia, and 10,929 in Poland. It would seem that the data are satisfactory. However, this number is decreasing each year. Compared to 2011, where more than 17,000 people graduated in nursing in Poland, the number of 10,929 is very worrying. However, almost all European Union countries are struggling with this problem [7].

Health care is one of the largest employment sectors in the European Union (it employs around 8\% of EU citizens). Despite the fact that the European Union aims to minimize inequalities in access to health services, there are still significant differences 
between Member States $-5.9 \%$ of GDP is allocated to health care in Romania and $12 \%$ in the Netherlands. Currently, the main problem of the European Union is the migration of medical staff. This is because of the principle of free movement of persons, services, goods, and capital. This right also guarantees equal treatment for all employees who are Union citizens. In Poland, there is no obligation to register medical personnel who go to work abroad. And the interest of citizens of other countries in working in Poland is small. It was less than $1 \%$ of all registered doctors and dentists in 2009. Therefore, this law is favourable to all medical personnel who are willing to migrate to countries that offer better working conditions (both financial and comfort of work). On the other hand, member states have to deal with inequalities in the supply of medical staff. Therefore, the European Union is seeking to improve the movement of people from the health care sector through agreements between member states on surplus medical staff, the introduction of reciprocal movement of workers, and support for foreign training and internships $[8,9]$.

Nursing is still associated in many countries with a "less intelligent symbol of sexuality". This is one of the factors conditioning low respect for nurses. The biggest problem of modern nursing is the negative image of this profession created in the media. In the popular TV series House M.D. and Grey's Anatomy, there were a total of about 20 major characters who were doctors, but not a single nurse. Nurses are no longer seen as an invisible or passive partner of a doctor, but as a person contributing to the well-being and health of patients. Nursing in France is at the stage of strong transformation and modernization of their competences, which will be legally included in the code. However, the most important problem is the lack of nurses [10]. The current situation in Slovakia shows that the nursing profession is clearly dominated by women; of 47,144 registered nurses and midwives, as many as $98.54 \%$ are women and only $1.46 \%$ are men (686) [11]. In a study conducted in 2014 in Portugal, the respondents indicated that the main source of knowledge about medical novelties were doctors (22.5\%). Studies from 2010 conducted on 210 patients of the São Teotónio de Viseu hospital indicate that the values appreciated by patients include: competence, friendliness, and knowledge, which the respondents indicated as one of the most common features of nurses. $21.27 \%$ of respondents indicated competence and $17.97 \%$ friendliness. However, the features that are more valued than the competences of nurses are availability, professionalism, technical skills, and humility. As many as $43.3 \%$ of respondents indicated that the nurse is a doctor's assistant. In the respondents' opinion, such features as the age and gender of the nurse are not related to their competence. The same study found an aver- age relationship between the place of residence (rural and urban areas) and the provision of health care and management, as well as interpersonal relations with nurses.

The importance attached to the quality of health care is greater in people whose hospitalization time ranged from 5 to 20 days. The image of nursing has changed a lot in recent decades. Despite this, nurses are still barely noticed in the media: out of 946 analysed articles on health, only 61 concerned nursing [12, 13].

The data obtained show that in post-communist countries, a less positive image of nursing dominates compared to Western European countries. This is probably because Poland and Slovakia joined the European Union much later, and thus introduced changes regarding the modern nursing system much later. The social position and prestige of the nursing profession, according to CBOS (Centre for Public Opinion Research) surveys, is increasing. However, it will take a long time and much effort to reach the level of France or Portugal.

\section{CONCLUSIONS}

Diversification of the social image of the nurse was observed; higher scores were given by respondents in France and Portugal, and lower by Poland and Slovakia.

Higher image scores are associated with higher public knowledge about this profession and greater trust in nurses.

In all countries surveyed, the respondents pointed out that the remuneration for the work of a nurse is too low.

Among the personality traits preferred in the profession of a nurse, some variation was observed; in general, however, responsibility, care, and patience were highlighted in all studied countries.

\section{STRENGTHS AND LIMITATIONS OF THE STUDY}

This is the first study of this type comparing the image of nurses between selected European Union countries. A "nurse image indicator" was created, which has not been developed before. We are aware that our research has some limitations. The first is the small research group. However, as indicated in the title, these are preliminary studies, and we plan to expand them. Another is to translate the questionnaire only into English, and not into the languages of the countries surveyed (except for Poland, where the authors of the article come from), so the average age of the respondents has been reduced. However, this was intentional because we wanted to reach the younger part of society. 


\section{ETHICAL APPROVAL}

The study was carried out in accordance with the ethical principles of the Helsinki Declaration.

\section{Disclosure}

The authors declare no conflict of interest.

\section{References}

1. Domański H. Prestiż. Wydawnictwo Naukowe Uniwersytetu Mikołaja Kopernika, Toruń 2012.

2. Ten Hoeve Y, Janses G, Roodbol P. The nursing profession: public image, self-concept and professional identity. A discussion paper. J Adv Nurs 2014; 70: 295-309.

3. Bridges JM. Literature review on the images of the nurse and nursing in the media. J Adv Nurs 1990; 15: 850-854.

4. Twaddle AC, Hessler RM. A sociology of health. Macmillan, New York 1987.

5. Kołodziej A. Czynniki określające status społeczny pielęgniarek. Hygeia Public Health 2014; 49: 69-74.

6. Włodarczyk D, Tobolska B. Wizerunek zawodu pielęgniarki z perspektywy lekarzy, pacjentów i pielęgniarek. Medycyna Pracy 2011; 62: 269-279.

7. Eurostat. European statistics. Health graduates. Available from http://appsso.eurostat.ec.europa.eu/nui/submitViewTableAction.do (26.04.2017).

8. Eurostat. European statistics. Health personnel by NUTS 2 regions. Available from: http://appsso.eurostat.ec.europa. eu/nui/submitViewTableAction.do (26.04.2017).

9. Rabiej E. Polityka Unii Europejskiej wobec personelu medycznego - narzędzie zrównoważonego rozwoju społecznego. Nierówności Społeczne a Wzrost Gospodarczy 2015; 43: 151-162.

10. Habib H, Nassar J. L'Image de l'Infirmière aujourd'hui. Journal Association FSI - USJ 2007; 33-35

11. Gračko M, Laurinc M. Postavenie mužov v ošetrovatel'stve na slovensku v 21. Storočí. Matriały zjazdowe: Ošetrovatel'stvo medzi teóriou a praxou. Tatranská Kotlina 2011; 70-76.

12. Martins M, Dias M. Representação socioprofissional dos enfermeiros - percepção dos utentes. RE - Número 38; Junho de 2010.

13. Cardoso RJM, de Nascimento Graveto JMG, Correia Albuquerque Queiroz AM. The exposure of the nursing profession in online and print media. Rev Lat Am Enfermagem 2014; 22: 144-149. 